\section{GROLND-WATER ISSUES}

Ground water is the principal source of freshwater for public supply, rural, industrial. and irrigation demands in Florida. The dependency of these uses on ground water in 1985 was, in percentages: public supply-89; rural/domestic-100; industrial-86; and irrigation-55. All uses combined withdrew an average of 4,030 million gallons per day of fresh ground water in 1985. The continuing rapid growth in Florida's population is increasing demands on the State's ground-water resources for supplies of high-quality potable water. Although abundant statewide. fresh ground water is in limited supply in some coastal areas and its withdrawal commonly causes seawater encroachment.

Florida's principal aquifers consist of sand at land surface and limestone and dolomite at depths of less than a few hundred feet. Together, the surficial sands and the limestone and dolomite form an enormous ground-water reservoir that provides large quantities of ground water. Owing to the fact that they are at or near land surface, these aquifers are vulnerable to contamination from various activities at the land surface.

Owing to the dependency on ground water, the rapidly growing population, and the vulnerability of the aquifers to contamination. the principal ground-water issues in Florida include:

- Ground-water quality management:

- Ground-uater availability:

- Seawater intrusion:

- Contamination from wasteviater disposal:

- Contamination from landfills and hazardous-waste sites; and

- Contamination from agricultural practices.

\section{U.S. GEOLOGICAL SURVEY PROGRAMS}

The U.S. Geological Survey (USGS), established in 1879, is the principal source of scientific and technical expertise in the earth sciences within the Federal government. USGS activities span a wide range of earth science research and services in the fields of geology, hydrology, and carography. The mission of the Water Resources Division of the USGS is to develop and disseminate scientific knowledge and understanding of the Nation's water resources.

The first ground-water study by the USGS in Florida began in 1910. In 1930, a cooperative program of study was started with the Florida Geological Survey, and in 1938, the first ground-water office of the USGS was established in Miami. The ground-water activities of the Water Resources Division in Florida are carried out by hydrologists, technicians, and support staff located in nine offices: Tallahassee, Tampa, Orlando. Miami. Jacksonville, For Myers, Stuart, Sarasota, and Ocala. Over the years, USGS investigators have published more than 350 reports on Florida's ground-water resources.

In fiscal year 1987, the USGS program in Florida included 35 active ground-water studies, all of which dealt with at least one of the principal ground-water issues. The 35 active studies were divided among the issues as follow's:

- Ground-water quality management. 9 studies:

- Ground-water availability, 12 studies:

- Seavater intrusion. 3 studies:

- Contamination from wastewater disposal, 6 studies:

- Contamination from landfills and hazardous-waste sites. 3 studies: and

- Contamination from agriculrural practices. 2 studies.

The USGS program in Florida includes an extensive groundwater data-collection network. This network provides long-term records to assess the status of the ground-water resource and to suppon interpretive studies. In 1987 , continuous ground-uater level measurements were collected at 511 sites. and periodic measurements were made at 2,338 long-term-record sites and 1,487 short-term-record sites. Ground-water quality data were collected at 537 long-term-record sites and 165 short-term-record sites.

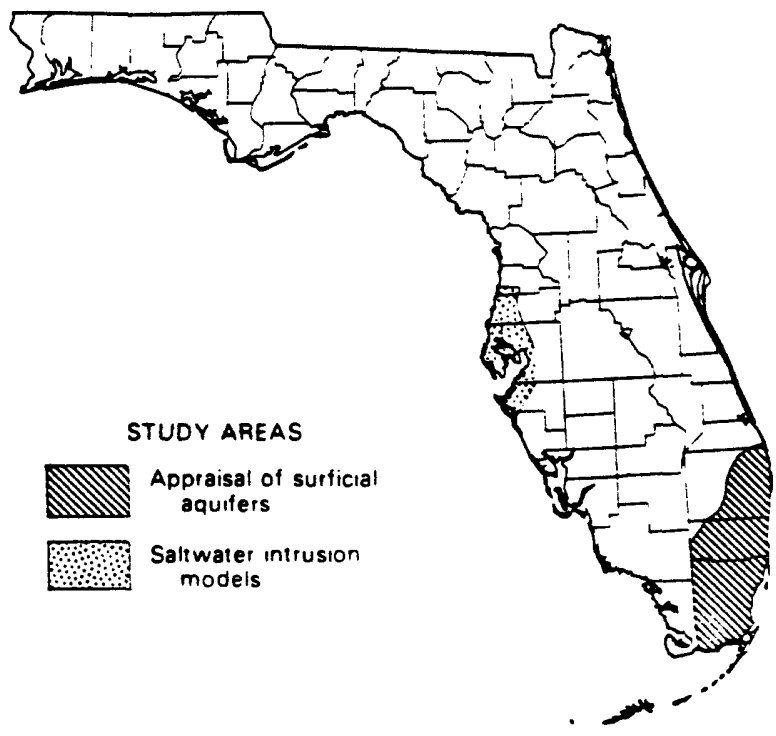




\section{SELECTED GROUND-WATER STUDIES}

\section{Delineation of Protection Zones Around Public-Supply} Wells

This statewide study is being done by the USGS in cooperation with the Florida Department of Environmental Regulation. The Department of Environmental Regulation has developed a rule for the protection of public-supply wells that are permitred to pump 100,000 gallons per day. Using the procedure specified by the rule, the USGS is evaluating hydrogeologic conditions and delineating the size and shape of the protection zones for these wells. This study is a forerunner of the Wellhead Protection Program recommended by the 1986 amendments to the Safe Drinking Water Act.

\section{Appraisal of the Surficial Aquifers of the Lower East Coast}

The Biscayne aquifer and associated aquifers supply nearly all of the drinking water for Palm Beach, Broward, and Dade Counties. Ground-water pumpage to supply the densely populated coastal areas of these counties may cause contamination of the aquifer from seawater intrusion. The USGS and the South Florida Water Management District have a cost-sharing agreement to study the Biscayne aquifer and associated aquifers. The study will provide detailed information on the ground-water flow system needed to manage withdrawals.

\section{Saltwater-Intrusion Models for Selected Areas, West-Central Coast}

Seawater intrusion into the heavily pumped well fields in the Tampa Bay area is being studied by the USGS in cooperation with the Southwest Florida Water Management District. The USGS is using computer models to define the physics of coastal ground-water flow systems and to predict the likely movement of the seawater interface toward inland pumping centers under various pumpage conditions. These models will provide the Southwest Florida Water Management District with information needed to manage pumpage and to control seawater intrusion.

\section{GROUND-WATER MANAGEMENT}

The principal State agencies responsible for ground-water management in Florida are the Florida Department of Environmental Regulation, the Northwest Florida Water Management District, the St. Johns River Water Management District, the South Florida Water Management District, the Southwest Florida Water Management District, and the Suwannee River Water Management District.
The Florida Department of Environmental Regulation is responsible for issuing permits for wastewater discharges and landfill siting, and for the statewide management of ground-water quality. The Water Management Districts are responsible for issuing permits to drill wells and pump ground water, and for the management of seawater intrusion. These agencies, in the execution of their responsibilities, use ground-water data and results of interpretive ground-water studies provided by the USGS. During 1987, these agencies, together with 59 other State and local agencies, entered into cost-sharing agreements with the USGS to support ground-water studies and data collection in Florida. Collectively, these cooperating agencies provided 46 percent of the $\$ 12$ million USGS water-resources program in Florida, of which more than one-half was devoted to groundwater studies and data collection.

\section{SELECTED REFERENCES}

Claiborne, Maude. Embry, T.L., Hoy, N.D., Weldon. D.H.. and Wilson, T.D., 1987. Bibliography of U.S. Geological Survey repons on the water resources of Florida, 1886-1986: U.S. Geological Survey Open-File Repon 85-424, 172 p.

Glenn. M.E.. ed.. 1987, Water resources activities in Florida. 1986-87: U.S. Geological Survey Open-File Repon 87-244, 98 p.

Franks, B.J., ed.. 1982, Principal aquifers in Florida: U.S. Geological Survey Water-Resources Investigations Open-File Report 82-255. 4 sheets.

Solley. W.B., Pierce. R.R.. Merck. C.F.. 1987. Preliminary water use estimates in the United States in 1985: U.S. Geological Survey OpenFile Repor 87-692, 5 p.

U.S. Geological Survey. 1984. Florida uater issues. in National uater summary 1983: U.S. Geological Survey Water-Supply Paper 2250. p. 106-108.

Vecchioli. John. and Foose, D.W.. 1985. Florida ground-u ater resources. in National water summary 1984: U.S. Geological Sune? Water-Supply Paper 2275, p. 173-178

For further information on ground-water interpretive studies and data collection in Florida. contact:

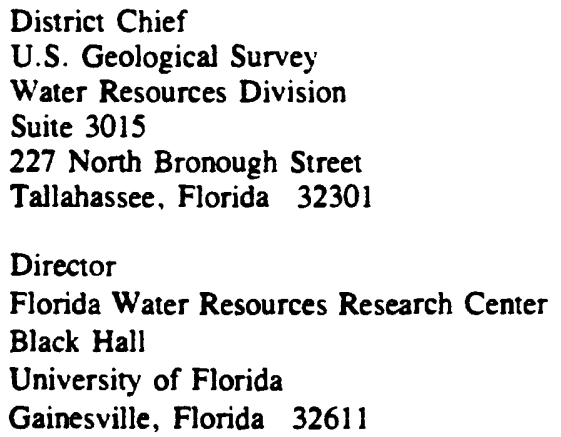

Open-File Report 88-107

John Vecchioli. 1988 